\title{
A Morphometric Study on the Skull of Donkey (Equus asinus)
}

\author{
Estudio Morfométrico del Cráneo del Burro (Equus asinus)
}

\author{
Lei Zhu",**; XiaoDong Shi"; JunJie Wang",** \& JianGang Chen"
}

ZHU, L.; SHI, X.; WANG, J. \& CHEN, J. A morphometric study on the skull of donkey (Equus asinus). Int. J. Morphol., 32(4):13061310, 2014.

SUMMARY: The present study was carried out on a number of 16 skulls of adult male domestic donkeys. Craniometric measurements for 40 different parts of the skulls were made. All investigated features were expressed as Mean \pm SD. Cephalic indices and ratios were calculated by using the investigated features. The craniometric measurements and cephalic indices had been compared with those of local horses and ponies. A skull length of $443.07 \pm 53.57 \mathrm{~mm}$ and a maximum zygomatic width of $169.09 \pm 17.64 \mathrm{~mm}$ were obtained. The size of donkey skull was between those of local horses and ponies. A skull index of $38.23 \pm 0.85$, a cranial index of $45.01 \pm 2.83$ and a facial index of $67.80 \pm 3.79$ were obtained. Cranial index and skull index were found to be close in value to that of local horses and ponies. The results of this study revealed that donkey had a longer nose than local horse and pony, and the difference of skull length in the three species accounted for the facial length difference.

KEY WORDS: Skull; Donkey; Craniometry.

\section{INTRODUCTION}

Donkey belongs to the family Equidae and is similar to horse in many ways. However, donkey is not just a smaller inferior type of horse, such as longer ears and short upright mane (Burnham, 2002). The knowledge of morphometric measurements of skull is of great importance for surgical treatment of pathological conditions and taxonomic affiliation. Previous studies on the skull shapes of animals measured directly from bare skulls (Simoens et al., 1994; Onar et al., 2001; Al-Sagair \& ElMougy, 2002; Özcan et al., 2010; Zhu, 2012). Evans \& Mcgreevy (2006) established a method for evaluating equine skull morphology that could also be used in live horses. Radinsky (1984) considered the ontogeny and phylogeny in horse skull evolution.

As a main source of work power and meat, donkey is an important domestic breed in high-altitude areas like Yunnan-Guizhou Plateau. Donkeys in Yunnan (a province in Southwest China) are less than 36 inches at the withers, and are identified as miniature donkey. No study on the craniometry of donkey has been reported, and this study was undertaken to establish a baseline data on the morphometric measurements of donkey skull. The skull indices and ratios were calculated and compared with the ones of local horses and ponies reported by Jie (1995). This may demonstrate the differences between the skulls of donkeys and horses.

\section{MATERIAL AND METHOD}

Sixteen skulls of adult male donkeys were used in this study. These heads were selected from an abattoir based on good health conditions and without any skeletal deformities. The skulls were macerated in accordance with the method described by Simoens et al. and Onar et al. Forty different craniometrical parameters were recorded with the help of measuring scale and thread vernier calipers. These measurements were made by using the methods described by Onar et al., Özcan et al. and Zhu. All investigated parameters were expressed as mean \pm SD. Definitions of measuring points of cranium were those described by Zhu. The following measurements of the cranium were made (Figs. 1-4): skull length: prosthion-akrokranion, facial length: prosthion-frontal midpoint, upper neurocranium length: frontal midpoint-akrokranion, viscerocranial length: prosthion-nasion, cranial length: nasion-akrokranion, short upper cranium length: rhinion-akrokranion, greatest length of nasals: the crossline of the two sides of the nasal bonesrhinion, nasal suture length: rhinion-nasion, least breadth between the infraorbital foramen, least breadth between the orbits: entorbitale - entorbitale, least breadth between the supraorbital foramen, least frontal breadth: breadth at the postorbital constriction, greatest neurocranium breadth: euryon- euryon, greatest breadth between the orbits: ectorbitale- ectorbitale, greatest breadth across the nasals,

\footnotetext{
"Key Laboratory of Yunnan Province, Universities of the Diversity and Ecological Adaptative Evolution for Animals and Plants on YuiGui Plateau. ${ }^{* *}$ College of Biology and Environmental Science, Qujing Normal University, Yunnan, P. R. China.
} 


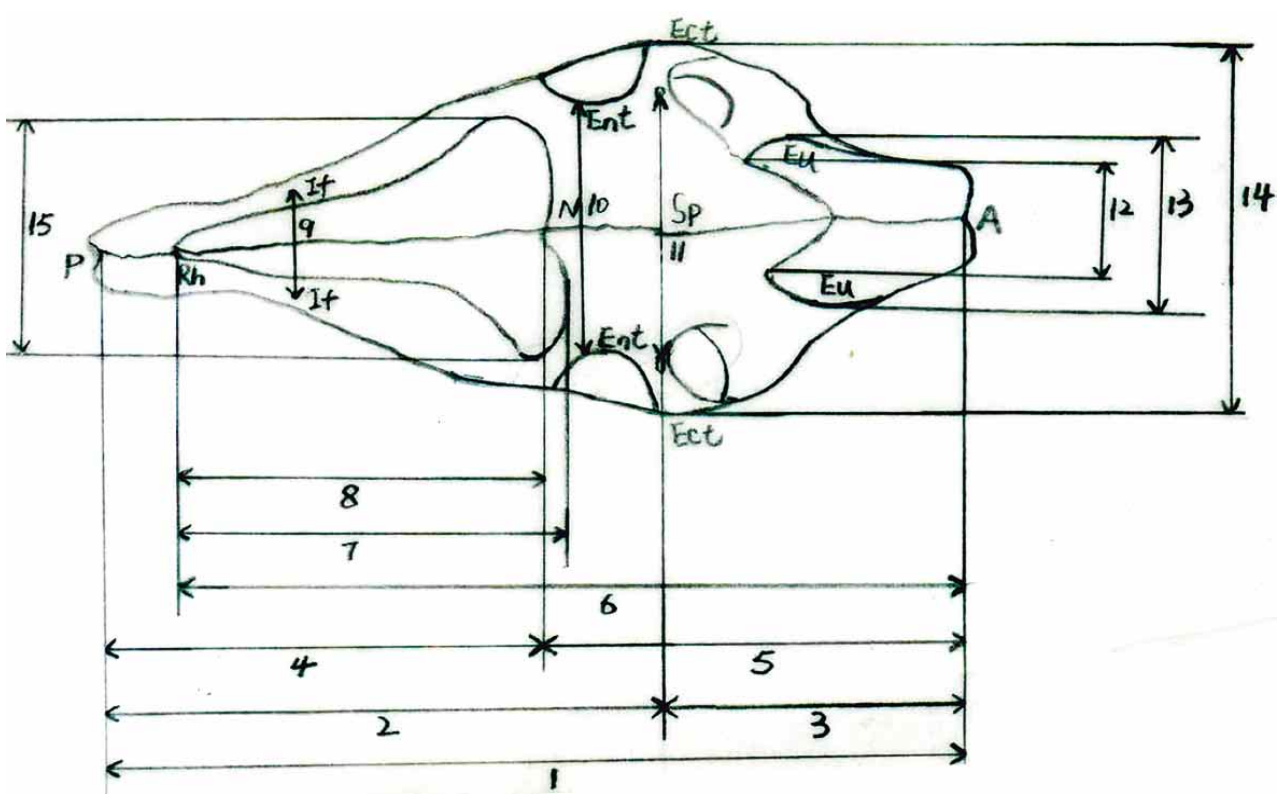

Fig. 1. Measurements of the skull of the donkey (dorsal view). A: Akrokranion, Ect: Ectorbitale, Ent: Entorbitale, Eu: Euryon, If: Infraorbitale, N: Nasion, P: Prosthion, Rh: Rhinion, Sp: Supraorbitale. 1: skull length, 2: facial length, 3: upper neurocranium length, 4: viscerocranium length, 5: Cranial length, 6: short upper cranium length, 7: greatest length of nasals, 8: nasal suture length, 9: greatest breadth across the premaxillae, 10: least breadth between the orbits, 11: least breadth between the infraorbital foramen, 12: least frontal breadth, 13: greatest neurocranium breadth, 14: greatest breadth between the orbits 15: greatest breadth across the nasals.

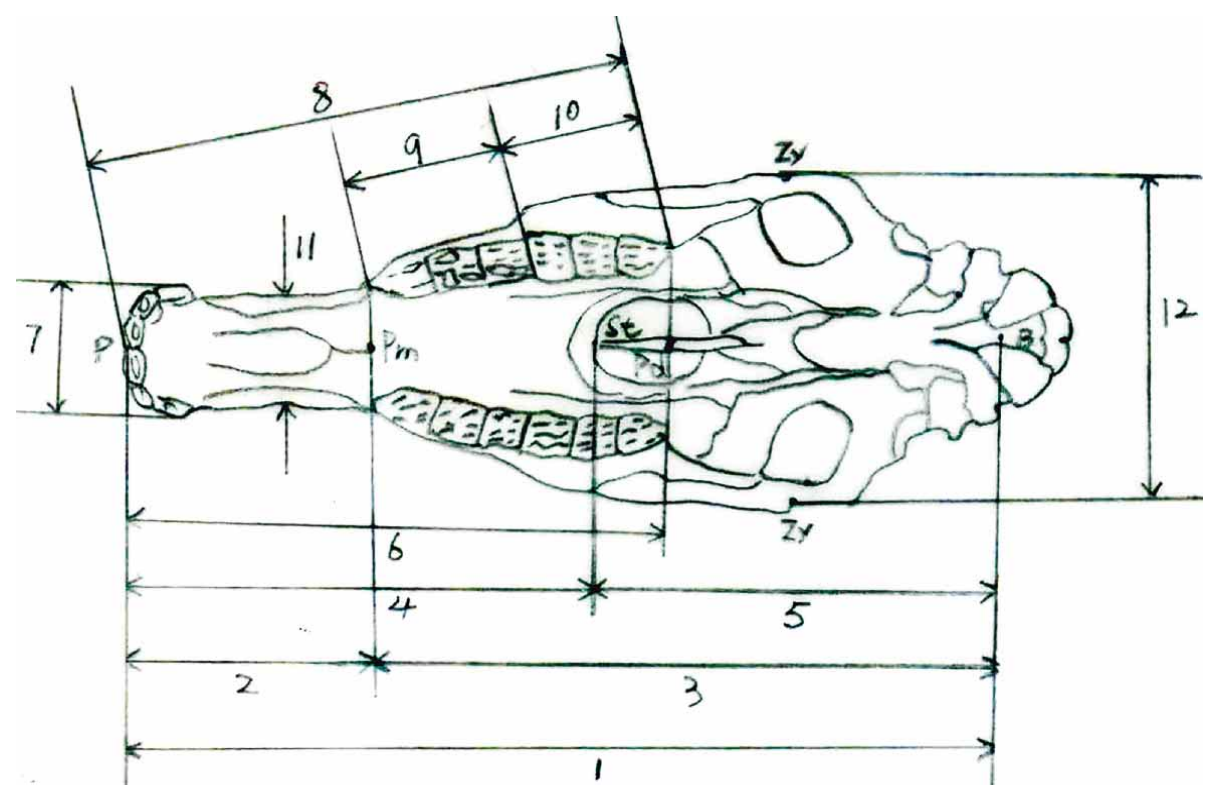

Fig. 2. Measurements of the skull of the donkey (ventral view). B: Basion, P: Prosthion, Pd: Postdentale, Pm: Premolare, St:Staphylion Zy: Zygion. 1: basal length, 2: premolare-prosthion, 3: short skull length, 4: median palatal length, 5: Basion- Staphylion, 6: palatal length, 7: Greatest breadth of snout 8: length of the tooth row, 9: length of the premolar row, 10: length of the molar row, 11: least breadth in the region of the diastema, 12: maximum zygomatic breadth. 

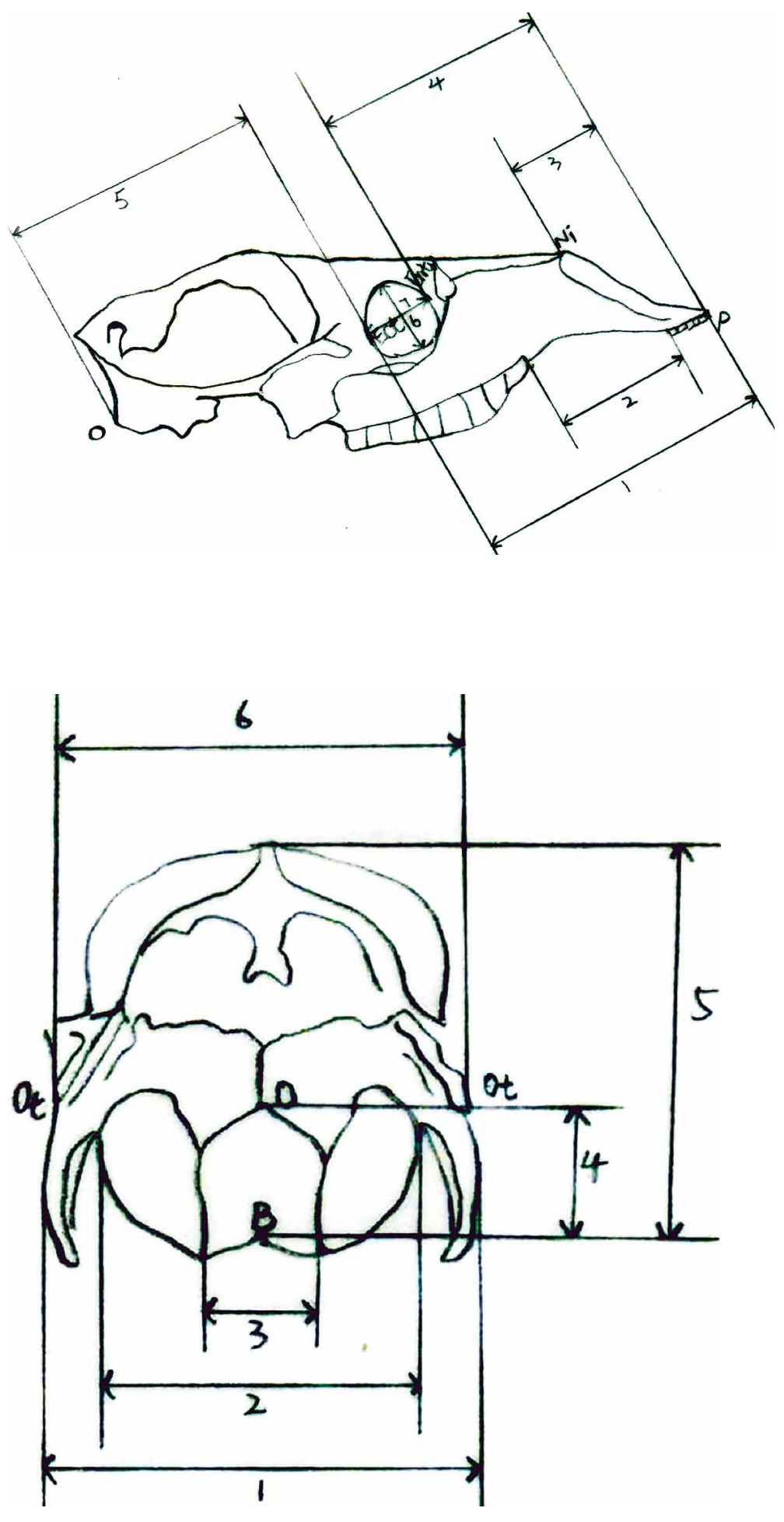

Fig. 4. Measurements of the skull of the donkey (occipital view). B: Basion, O: Opisthion, Ot: Otion. 1: greatest breadth of the bases of the paraoccipital processes, 2: Greatest breadth of the occipital condyles 3: greatest breadth of the foramen magnum, 4 : height of the foramen magnum, 5: Skull height, 6: greatest mastoid breadth.
Fig. 3. Measurements of the skull of the donkey (lateral view). B: Basion, Ect: Ectorbitale, Ent: Entorbitale, Ni: Nasointermaxillare, P: Prosthion. 1: lateral facial length, 2: length of the diastema, 3: lateral length of the premaxilla, 4: short later facial length, 5: length of the braincase, 6: greatest inner length of the orbit, 7: greatest inner height of the orbit.

basal length: prosthion- basion, premolareprosthion, short skull length: premolare basion, median palatal length: prosthionstaphylion, basion- staphylion, palatal length?the median point of the intersection of the line joining the deepest indentations of the choana- prosthion, greatest breadth of snout, length of the tooth row, length of the premolar row, length of the molar row, least breadth in the region of the diastema, maximum zygomatic breadth: zygionzygion, lateral facial length: prosthionectorbitale, length of the diastema, lateral length of the premaxilla: prosthionnisointermaxillare, short later facial length: prosthion- entorbitale, length of the braincase: ectorbitale-opisthion, greatest inner length of the orbit, greatest inner height of the orbit, greatest breadth of the bases of the paraoccipital processes, greatest breadth of the occipital condyles, greatest breadth of the foramen magnum, height of the foramen magnum, skull height: basion-external occipital crest, greatest mastoid breadth: otion-otion.

The cephalic indices and ratios were calculated as described by Onar et al. Skull index: Maximum zygomatic width X100/ skull length, Cranial index: Maximum width of the neurocranium X100/cranial length, Facial index: Maximum zygomatic width X100/ Viscerocranial length. 


\section{RESULTS AND DISCUSSION}

The craniometric measurements of donkey skulls were evaluated. The Mean \pm SE of the investigated features were presented in Table I. These craniometric measurements were compared with the literature about local horses and ponies reported by Jie. A skull length of $443.07 \pm 53.57 \mathrm{~mm}$ and a maximum zygomatic width of $169.09 \pm 17.64 \mathrm{~mm}$ were obtained. The skull length and maximum zygomatic width of local horse were $468.33 \pm 9.83 \mathrm{~mm}$ and $175.12 \pm 9.35 \mathrm{~mm}$, and those of ponies were $415.83 \pm 13.93 \mathrm{~mm}$ and $159.10 \pm 12.54 \mathrm{~mm}$. This revealed that the size of the skull of donkey was between those of the local horse and pony. Radinsky and Evans \& Mcgreevy argued that when evaluating skull length for comparison, it was important to consider the skull as being composed of two major components: the cranial portion and the nasal portion. The facial lengths of local horse, donkey and pony were $381.67 \pm 23.46 \mathrm{~mm}, 302.64 \pm 43.09 \mathrm{~mm}$ and $286.67 \pm 0.53 \mathrm{~mm}$; the cranial lengths were $207.82 \pm 22.2 \mathrm{~mm}, 205.33 \pm 6.6 \mathrm{~mm}$ and $203.00 \pm 7.94 \mathrm{~mm}$. These revealed that the face length of donkey was between those of local horses and ponies, and the difference of the skull length in the three species accounted for the facial length difference.

Evans \& Mcgreevy investigated that the skull length and maximum zygomatic width of three popular equine breeds (standardbred, thoroughbred and Arabian) were $476 \pm 38.86 \mathrm{~mm}$ and $163.7 \pm 14.20 \mathrm{~mm}$, and they used the distance of the dorsal lateral nasal cartilages to the external occipital protuberance as the skull length, so the skull length of these breeds would be longer than the data in their article if they used measure points in this study. This revealed that donkey had a shorter but wider skull than the popular equine breeds.

The maximum lengths of the nasals of donkey, horse and pony were $207.34 \pm 35.07 \mathrm{~mm}$, $186.97 \pm 11.88 \mathrm{~mm}$ and $167.33 \pm 10.13 \mathrm{~mm}$ respectively. This revealed that donkey had a longer nose than local horses and ponies. Evans $\&$ Mcgreevy and Ozcan et al., used the nasionrhinion as the greatest length of the nasals, but the authors used the crossline of two sides of
Table I. The mean value of skull measurements of the adult domestic donkey $(\mathrm{mm})$.

\begin{tabular}{lc}
\hline Measurements of the cranium & Mean \pm SD \\
\hline Skull length & $443.07 \pm 53.57$ \\
Facial length & $302.64 \pm 43.09$ \\
Upper neurocranium length & $159.11 \pm 15.75$ \\
Visceroc ranium length & $250.92 \pm 37.44$ \\
Cranial length & $207.82 \pm 22.2$ \\
Short upper cranium length & $386.77 \pm 51.95$ \\
Greatest length of the nasals & $207.34 \pm 35.07$ \\
Nasal suture length & $192.08 \pm 31.41$ \\
Least breadth between the infraorbital for amen & $70.21 \pm 6.61$ \\
Least breadth between the orbits & $125.47 \pm 13.97$ \\
Least breadth between the supraorbital foramen & $116.62 \pm 14.11$ \\
Least frontal breadth & $75.88 \pm 5.39$ \\
Greatest neurocranium breadth & $93.06 \pm 5.80$ \\
Greatest breadth between the orbits & $128.61 \pm 12.96$ \\
Greatest breadth across the nasals & $94.34 \pm 10.48$ \\
Basal length & $389.24 \pm 49.11$ \\
Premolare-prosthion & $99.88 \pm 16.57$ \\
Short skull length & $325.26 \pm 64.64$ \\
Median palatal length & $204.11 \pm 27.00$ \\
Basion- Staphylion & $190.61 \pm 17.27$ \\
Pala tal length & $239.82 \pm 33.81$ \\
Greatest breadth of the snout & $49.42 \pm 6.69$ \\
Length of the tooth row & $144.55 \pm 16.58$ \\
Length of the premolar row & $75.76 \pm 12.71$ \\
Length of the molar row & $70.34 \pm 7.60$ \\
Least breadth in the region of the diastema & $38.98 \pm 4.37$ \\
Maximum zygomatic width & $169.09 \pm 17.64$ \\
Lateral facial length & $277.54 \pm 43.94$ \\
Length of the diastema & $69.45 \pm 15.59$ \\
Lateral length of the premaxilla & $140.14 \pm 19.27$ \\
Short lateral facial length & $263.99 \pm 42.78$ \\
Length of braincase & $187.71 \pm 28.57$ \\
Greatest inner length of the orbit & $53.13 \pm 5.26$ \\
Greatest inner height of the orbit & $47.72 \pm 4.53$ \\
Greatest breadth of the bases of the paraoccipital process & $90.85 \pm 9.47$ \\
Greatest breadth of the occipital condyles & $68.78 \pm 8.72$ \\
Greatest breadth of the for amen magnum & $29.86 \pm 2.07$ \\
Skull height & $31.35 \pm 2.83$ \\
\hline & \\
Greatest mastoid breadth & \\
&
\end{tabular}

nasal bones to the rhinion instead in this study due to the nasal bones were convex at its dorsal surface.

The indices and ratios of donkeys were calculated by using the investigated features. The skull, cranial and facial indices are shown in Table II, and these indices were compared with the ones of local horses and ponies reported by Jie (1995) and three popular equine breeds reported by Evans \& Mcgreevy. A skull index of $38.23 \pm 0.85$, a cranial index of $45.01 \pm 2.83$ and a facial index of $67.80 \pm 3.79$ were obtained. 
Table II. The index of the donkey comparison with literature.

\begin{tabular}{lcccc}
\hline \multirow{2}{*}{ Donkey } & \multicolumn{2}{c}{$\begin{array}{c}\text { Jie } \\
(\mathbf{1 9 9 5})\end{array}$} & $\begin{array}{c}\text { Evans \& McGreevy } \\
(\mathbf{2 0 0 6})\end{array}$ \\
\cline { 3 - 5 } & & Local horse & Pony & Three popular breeds \\
\hline Skull index & $38.23 \pm 0.85$ & 37.39 & 38.26 & $34.48 \pm 2.61$ \\
Cranial index & $45.01 \pm 2.83$ & 46.35 & 45.13 & $68.06 \pm 6.67$ \\
Facial index & $67.80 \pm 3.79$ & 70.33 & 73.15 & -- \\
\hline
\end{tabular}

Cranial index and skull index were found to be close in value to that of local horses and ponies. However, the facial index was found to be smaller than the ones of local horses and ponies. Skull index of the three popular breeds was smaller than that of donkey. However, Evans \& Mcgreevy used the cranial width x 100/cranial length to calculated the cranial index, so the cranial index of the three popular breeds was found to be bigger than that of donkey. The data obtained in this study may be of some use in the clinical treatments of diseases, such as osteomyelitis of frontal bone.

ZHU, L.; SHI, X.; WANG, J. \& CHEN, J. Estudio morfométrico del craneo del burro (Equus asinus). Int. J. Morphol., 32(4):13061310, 2014.

RESUMEN: Se realizó un estudio sobre una serie de 16 cráneos pertenecientes a burros domésticos adultos, de sexo masculino. Se hicieron mediciones craneométricas en 40 partes diferentes de las muestras. Todas las características investigadas se expresaron como media \pm desviación estándar, calculándose índices y proporciones cefálicas. Se compararon las mediciones craneométricas e índices cefálicos con los de caballos y ponis de la

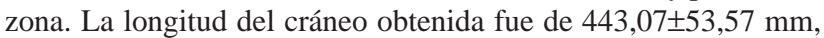

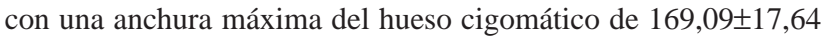
$\mathrm{mm}$. El tamaño del cráneo del burro se ubicó entre el de los caballos y los ponis locales. Se obtuvo un índice de cráneo de $38,23 \pm 0,85$, un índice craneal de $45,01 \pm 2,83$ y un índice facial de $67,80 \pm 3,79$. Los índices craneal y de cráneo encontrados fueron cercanos a los valores correspondientes a los caballos y ponis locales. Los resultados de este estudio revelaron que el burro tenía una nariz más larga que el caballo y el poni. Además, la diferencia en longitud del cráneo en las tres especies representa la diferencia de longitud facial.

PALABRAS CLAVE: Cráneo; Burro; Craneometría.

\section{REFERENCES}

Al-Sagair, O. \& ElMougy, S. A. Post-natal development in the linear and tric morphometrics of the camelidae skull. Anat. Histol. Embryol., 31(4):232-6, 2002.

Burnham, S. L. Anatomical differences of the donkey and mule. Proc. Annu. Conv. AAEP, 48:102-9, 2002.
Evans, K. E. \& McGreevy, P. D. Conformation of the equine skull: a morphometric study. Anat. Histol. Embryol., 35(4):221-7, 2006.

Jie, D.W. The compare research of the skull of the pony and the horse in Yunnan. Yunnan J. Anim. Sci. Vet. Med., 23(1):22-5, 1995.

Onar, V.; Ozcan, S. \& Pazvant, G. Skull typology of adult male Kangal dogs. Anat. Histol. Embryol., 30(1):41-8, 2001.

Özcan, S.; Aksoy, G.; Kürtül, I.; Aslan, K. \& Özüdogru, Z. A comparative morphometric study on the skull of the Tuj and Morkaraman sheep. Kafkas. Univ. Vet. Fak. Derg., 16(1):1114, 2010

Radinsky, L. Ontogeny and phylogeny in horse skull evolution. Evolution, 38:1-15, 1984.

Simoens, P.; Poels, P. \& Lauwers, H. Morphometric analysis of the foramen magnum in Pekingese dogs. Am. J. Vet. Res., 55(1):34-9, 1994.

Zhu, L. Craniometrical studies on the skull of tibetan gazelle (Procapra Picticaudata). Int. J. Morphol., 30(1):196-8, 2012.

Correspondence to:

Dr. Lei Zhu

San Jiang Road

QiLin District

Yunnan-Guizhou Plateau Institute of Biodiversity

College of Biology and Environmental Science

QuJing Normal University

QuJing, Yunnan

P. R. CHINA

Email: zhulei82@gmail.com

Received: 14-02-2014

Accepted: 16-09-2014 